\title{
A caution on handling Trachycephalus venulosus (Anura: Hylidae); toxic effects of skin secretion on human eyes
}

\author{
TOM W. BROWN
}

Kanahau Utila Research \& Conservation Facility, Isla de Utila, Isla de la Bahia, Honduras

*Author e-mail: tom@kanahau.org

$T^{n}$ he milky or veined treefrog Trachycephalus venulosus (Laurenti, 1768), is a large, robust, arboreal species distributed widely across the neotropics (Fig. 1). It is the only member of its genus (totalling 12 species) to occur in Central America (Frost, 2020) and inhabits a range of primary and disturbed habitat types. It can be identified using the guide to Central American amphibians by Kohler (2011).

Numerous guidebooks heed caution when handling $T$. venulosus, referring to its ability to secrete a large amount of sticky, white, volatile, poisonous, alkaline, water insoluble mucus that is highly irritating to mucous membranes (Savage, 2002; Kohler, 2011). These collagenous proteinbased secretions have been demonstrated to discourage potential predators (e.g. snakes - Yeager et al., 2019), as well as reduce cutaneous water loss (McDiarmid, 1968). The exact chemical composition of $T$. venulosus secretions remain undetermined; however, various literature documenting the effects of Trachycephalus secretions suggest they can cause harm to humans (Smith, 1941; Duellman 1956; Tanecs \& Littlefair, 2014). According to those studies, human reactions to $T$. venulosus secretions can be extremely painful, and include symptoms such as sneezing, skin irritation, rashes, swelling, and even temporary blindness. In support, the following note details my own experiences with the skin secretions of this frog.
On the 25 September 2015, I was in the region of La Democracia, Belize District, Belize $\left(17^{\circ} 21^{\prime} 27.9^{\prime \prime} \mathrm{N}\right.$ $\left.88^{\circ} 32^{\prime} 32.9^{\prime \prime} \mathrm{W}\right)$. At $21.15 \mathrm{~h}$, I encountered an adult hylid frog on a high branch in vegetation next to a water pool. At that time, I was not familiar with $T$. venulosus and in order to make an identification I carefully captured the frog (sex unknown) with moist (insect-repellent-free) hands and promptly released it on a lower perch so I could photograph and observe its defining characteristics more closely. The individual was held in-hand for less than 20 seconds, not subject to excessive stress, nor did it visibly secrete any white mucus in response to capture. However, within five minutes of capturing the individual, I began to develop a rash-like burning sensation on my forehead, after unintentionally wiping sweat from it using my hand. Before I understood what was causing the irritation, I proceeded to further touch and wipe my forehead, which combined with running sweat, then transferred the irritant into my eyes. Immediately, I developed intense localised pain in both eyes, visual impairment and uncontrollable eye watering as a response. Understanding the possible seriousness of my situation, I quickly made my way to a nearby tap and mirror and proceeded to wash my hands and face with soap, and flush my eyes with fresh water. For about 30 minutes after, I could barely keep both eyes open owing to sharp burning pains, despite vigorously

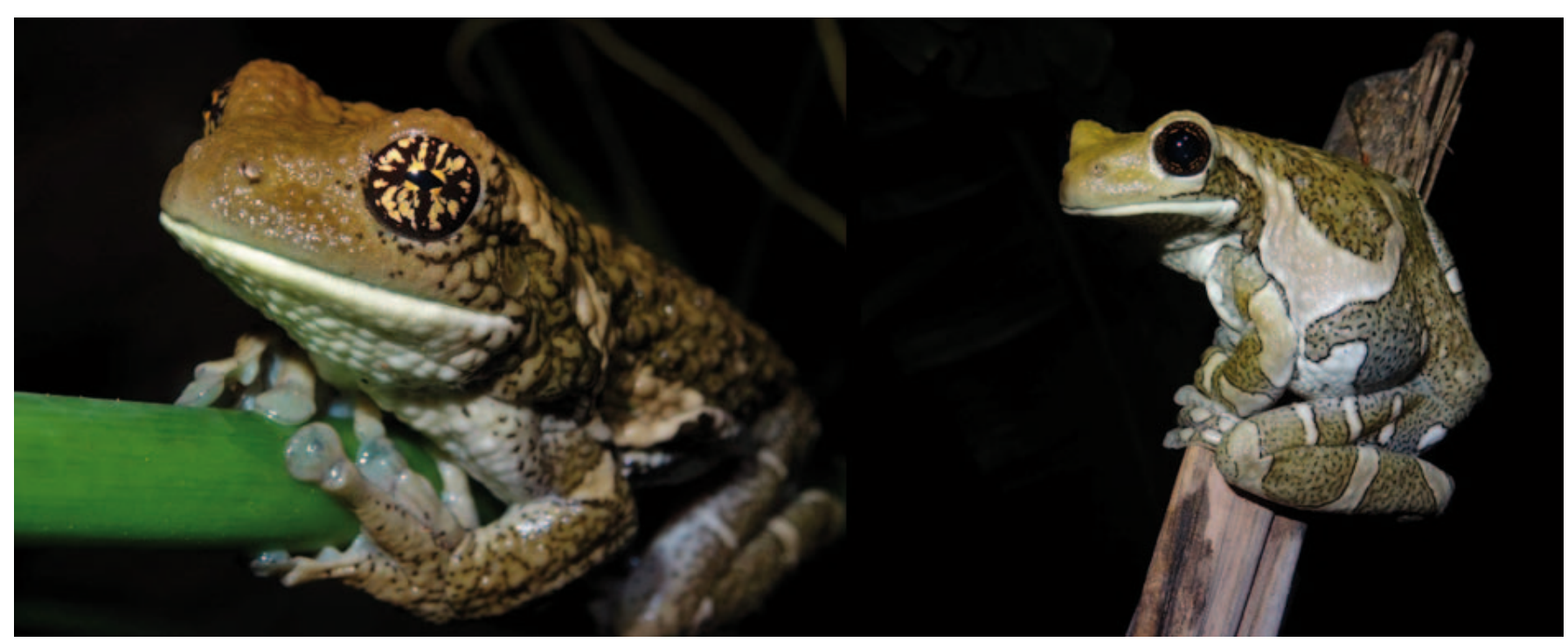

Figure 1. Trachycephalus venulosus at the reported locality in Belize 
irrigating them with water during that time. In total, it took approximately 90 minutes for normal vision to return and the pain to subside, with no side effects other than bloodshot eyes and slight inflammation of the facial skin around them. Now recovered, I successfully identified the hylid species as $T$. venulosus, and finally understood the error of my ways. I am a white Caucasian male with no known allergies and at the time was 22 years old.

In addition to documenting first-hand the effects of $T$. venulosus secretions, this case serves as a reminder to myself, and others, for the need to familiarise ourselves with the species present at study locations, follow correct fieldwork and handling protocols, always consider the potential hazards posed by native wildlife, and to avoid lone fieldwork where possible. Concerning $T$. venulosus and ideally all wild amphibians, capture and any necessary handling should always be performed wearing appropriate sterile gloves (Greer et al., 2009), to minimise any risk to the animal and provide a protective barrier between yourself and the amphibian.

\section{REFERENCES}

Duellman, W. E. (1956). The frogs of the hylid genus Phrynohyas Fitzinger, 1843. Miscellaneous Publications. Museum of Zoology, University of Michigan 96: 147.

Frost, D.R. (2020). Amphibian Species of the World: an Online Reference. Version 6.1 (04/03/2020). Electronic Database accessible at https://amphibiansoftheworld.amnh.org/ index.php. American Museum of Natural History, New York, USA. doi.org/10.5531/db.vz.0001
Greer, A., Schock, D., Brunner, J. et al. (2009). Guidelines for the safe use of disposable gloves with amphibian larvae in light of pathogens and possible toxic effects. Herpetological Review 40: 145-147.

Kohler, G. (2011). Amphibians of Central America. Offenbach, Herpeton Verlag. ISBN 3-936180-33-4.

McDiarmid, R. W. (1968). Populational variation in the frog genus Phrynohyas Fitzinger in Middle America. Contributions in Science of the Natural History Museum of Los Angeles County 134: 1-25.

Savage, J. M. (2002). The Amphibians and Reptiles of Costa Rica: A Herpetofauna between Two Continents, between Two Seas. The University of Chicago Press, Chicago, Illinois, United States. 595 pp.

Smith, H.M. (1941). Snakes, Frogs and Bromeliads. Chicago Natural History Museum Press 4: 35-43.

Tanecs, L. \& E. Littlefair (2014). Symptoms and treatment of acute conjunctivitis caused by skin secretions of veined tree frog (Trachycephalus venulosus). Wilderness \& Environmental Medicine 25: 486 - 487.

Yeager, J., Zarling, A. \& Rodríguez-López, C. (2019). Successful multimodal amphibian defence in the neotropical frog Trachycephalus, including handling and recovery costs to would-be predators. Herpetology Notes 12: 279-280.

Accepted: 12 March 2020 